\title{
Judgment (Trial) in Absentia According to the Code of Criminal Procedure of the Republic of Albania
}

\author{
Naim Tota \\ Klodjan Skenderaj \\ University of Tirana, Tirana, Albania
}

DOI: https://doi.org/10.36941/mjss-2021-0035

Abstract

The judgment in absentia of the defendant is included in the institutes provided in the Code of Criminal Procedure, where in many cases many problems have been encountered in our case law. The judgment in absentia must, on the one hand, guarantee the respect of the fundamental rights of the defendant and, on the other hand, guarantee the public interest in the administration of justice, through the regular exercise of judicial functions. In the Albanian legislation these conflicts of interest have been resolved by the legislator by accepting and becoming part of the Code of Criminal Procedure of 1995 as well as with the amendaments made in 2017, namely, the conduct of the trial in the absence of the defendant. However, this Code also guarantees the defendant the opportunity to review the matter, in cases where he becomes aware of the decision rendered in absentia. The guarantee placed by the legislator in the code of criminal procedure has come precisely because of the practice of the ECHR but also a series of decisions of the Constitutional Court of Albania, which stated that in cases of judgments rendered in absentia, defendants have the right to have their case reviewed. This paper will analyze exactly the provisions of the Albanian criminal procedural law on the conduct of the judgment in absentia, the cases of suspension of the trial for the defendants who do not know effectively about the trial.

Keywords: judgment in absentia, defendant, criminal process, timely reinstatement

\section{Introduction}

With the amendaments made in the Code of Criminal Procedure, Article 352 of this Code has been amended with Law no. 35/2017, by providing new rules on the conduct of judgment in absentia. However, before the court can make a decision on the conduct or judgment in absentia, it must be verified by the court from the investigative file brought for trial, if during the preliminary investigation the prosecutor has personally notified the defendant of the completion of the investigation as well as the request to send the case to trial. Based on the definition of Article 6 of the Code of Criminal Procedure, the Prosecutor's Office in cases where the person under investigation is not found, appoints from the list of available lawyers, a defense lawyer ex officio (public defender). The appointed (ex officio) counsel (public defender) appointed by the prosecution comes as a result of the inability of the person under investigation to determine a defense lawyer himself or with the help of his relatives, which is necessarily necessary to continue the investigation and then the trial, as 
a guarantee of protection of personal rights, but also the procedural ones of the person who has the status of a suspect for a certain criminal offense.

In the case of the defendant in absentia, the role of the lawyer or his defense lawyer differs from the role of the lawyer chosen by the defendant present. If the defendant present at the trial has the opportunity to contact his defense lawyer, the defendant in absentia is totally deprived of this right. Consequently, the appointed counsel will mainly protect the interests of the client who does not know him and who will not be constantly contacted to get acquainted with the continuity of the court process. Consequently, the investigation in absentia and the appointment of the defendant, despite the efforts of the registrar and the changes made to enable investigations in absentia, seem to have to some extent the form of a formal defense rather than an effective one.

\section{Suspension of the Trial in the Case of the Defendant in Absentia}

As quoted above, the Code of Criminal Procedure sanctioned judgment in absentia, always respecting the fundamental rights to a fair legal process. Respectively, Article 352 of the Code of Criminal Procedure clearly stipulates the cases of how and when a court hearing can take place in the absence of the defendant.

In case the defendant who is at large, despite any search, searches which are specified in Articles 140 to 142 of the Code of Criminal Procedure does not appear at the hearing and it turns out that he has not been personally notified about the trial, the court decides on the suspension of the main trial for one year and orders the judicial police to continue the search against the defendant.

After 1 year has passed from the moment of the suspension of the trial due to the nonappearance of the defendant and the result of not receiving notification about the trial and at any moment when there is information about the location of the defendant, the court resumes the trial, ordering the repetition of the notice. But if even after the newly conducted searches the defendant is not found, then the court declares the absence and the trial takes place in the presence of defense lawyer.

In additionj, it is argued in the doctrine that the court declares the absence and the trial takes place in the presence of the defense lawyer, when it is proved that the defendant is hiding from justice (Islami, Hoxha, \& Panda, 2012). Another case that offers the court the opportunity to declare absence is when it is proven that the defendant is abroad and his extradition is not feasible.

According to the provisions of the Code of Procedure of the Republic of Albania, the decision of the court to conduct the main judgment in absentia will be considered invalid, in case the absence or non-appearance of the defendant in the hearing has come as a result of absolute impossibility to appear. This means that, if after the court decision on the declaration of absence the defendant presents facts and evidence where it turns out that he was unable to appear, then consequently the interim decision on the declaration of absence may be declared void and invalid, and the trial develops from the beginning.

The court also has the obligation to revoke the decision on the conduct of the judgment in absentia when the defendant decides to appear at the hearing after the decision made. If the defendant appears at the hearing only after the main trial has been considered closed, then the defendant himself may request that the interrogation process be conducted against him. When the defendant requests the court and of course the latter deems it reasonable and in the best interest of the entire decision and the trial, he can declare the reopening of the main trial. Once the main trial has been reopened, any evidence or investigation previously conducted is considered valid but on the other hand new evidence identified and requested by the defendant can be obtained and procedural actions can be reopened.

Only the juvenile defendant, against whom a court decision cannot be taken in absentia, is excluded from the possibility to be included in the above procedural stages. This means that in the case of a trial against a missing juvenile, the court must suspend the trial.

Regarding the cases of conducting the judgment in absentia, we can say that this trial is applied 
mainly in cases when the defendant personally, voluntarily waives the right to appear at the trial. This means that the defendant refuses to take advantage of the right to appear at trial, or in the case where the defendant escapes from the police when the latter accompanies him as a detainee.

Another case concerns when the defendant did not appear at any hearing during the investigation or trial or when the defendant leaves the court hearing. If the defendant voluntarily waives his right to appear in court and the trial will take place in his absence, then the defendant by mail or his defense lawyer submits to the court a special power of attorney for the development of trial in his absence.

More specifically, Article 351 of the Code of Criminal Procedure stipulates:

\begin{abstract}
"When the defendant in free state or under precautionary detention in prison fails to appear in the hearing, despite being notified, and has no legitimate reasons for not appearing, the court shall postpone the hearing and order his forced accompaniment, unless he has declared, before a notary public or before the competent State authority, his will not to attend the trial. In this event, the trial shall continue in his absence. If the defendant who is present at the hearing, expressly renounces from his right to participate to trial, the trial shall continue in his absence. In cases provided for by paragraphs 1 and 2 of this article, the defendant shall be considered present, provided that the trial is conducted with the presence of the defence lawyer."
\end{abstract}

The same rule shall apply if the defendant leaves at any moment of the judicial trial or during its intervals.

\title{
3. Declaration of Absence of the Defendant
}

The court may decide on the trial in the absence of the defendant only if any procedural aspect determined by the Code of Criminal Procedure on the notification of the defendant regarding the initiation of a court process has been respected, as well as at the same time after also informed of the charge against him as a defendant. Although the defendant may have been notified once during the investigation process, the notification must be repeated during the trial from the beginning, and this must be done at every stage of the retrial to ensure a fair trial.

The court orders the recurrence of the summons, especially when it is established that the person who is in the status of the accused or even the defendant, has not received the necessary notification or even when the notification made against him is suspicious. At the same time, the court postpones or suspends the main trial by setting another date for the next hearing, ordering at the same time to repeat the summons if it is established that the person did not appear at the hearing as a result of force majeure or any other obstacle that excludes him from the responsibility of nonappearance.

The Code of Criminal Procedure, has sanctioned through the same article to follow the same rules even when the defendant is represented by a single defense lawyer. In this way, if the absence of counsel comes from reasons independent of him as may be the case of force majeure, the main trial may continue when the defendant, even though the defense counsel has been unable to appear at the hearing for reasons independent of his, again requests the conduct of the court hearing thus proceeding in the absence of the defense counsel and his presence is not a necessity. As mentioned above, this procedural aspect is followed only when we have a single defense counsel, because otherwise if the defendant is represented by two defense counsels, and the inability to appear at the hearing is related to only one of them, then the court hearing will takes place in the presence of the other defense counsel. If the defense counsel does not appear in court despite the fact that the notification against him has been duly made and we are not in conditions that exclude him from the obligation to appear as in the case of force majeure, then a sanction is imposed against the defense counsel in the form of a fine that can vary from ALL 5000 to ALL 100 ooo and, at the same time he can be ordered to pay the costs of the court session. 


\section{Procedural Guarantees of Judgment in Absentia}

The judgment in absentia shows the need for an increased guarantee of the rights of the defendant due to the inability to know beyond any reasoned doubt whether the defendant did not appear at the trial as a result of not receiving the notice, or of his own free will, despite its proper notification and procedure, the suspect has waived the right to be present at the trial (Lara, 2019). For this fact, according to Article 6 of the ECHR, the judgment in absentia is more problematic and complicated in relation to the trial conducted in the presence of the defendant.

Regardless of the presence of the defendant or not, the court hearing and then the trial as a whole is conducted keeping in mind any necessary procedure that is sanctioned in the Code. Beyond this fact, the very absence of the defendant causes a disfavor for him. However, the Code of Criminal Procedure provides guarantees for judgment in absentia, a guarantee which, if broken, will invalidate the court decision.

One of the guarantees that is defined in the Code of Criminal Procedure is the notification of the defendant according to articles 140 and 141 of the Code of Criminal Procedure. In order to ensure the rights of the person tried in absentia, who did not appear at the trial as a result of notification of the violation in accordance with the procedures set out in the code, ie to balance the incorrect notification, the institute of retrial of the case is provided with the procedure of reviewing the criminal decision. With the amendments to Law no. 35/2017 was intervened by the legislator in Article 450 of the Code of Criminal Procedure, adding the case when the defendant was tried in absentia. More specifically, this provision stipulates that a review may be requested when the person has been tried in absentia under Article 352 of the Code and a retrial of the case is requested. The request for review of the case is submitted within thirty days from the date of notification and that the request can not be requested. So, our legislator himself has provided an additional guarantee regarding the cases when the defendant has been tried in absentia, giving the latter the guarantee of reviewing the case against him. However, in order to be in the conditions of accepting the request for review of the final criminal decision, the court which will review the request for review of the case must perform all the necessary verifications, where in no case should the defendant be aware of the conduct of the trial in his absence. This verification of the court is related to the review of all summonses sent by the court, as well as all the minutes that document the conduct of court hearings.

However, it should be noted that the Code of Criminal Procedure, as for any step of the judgment in absentia, has sanctioned the methodology or procedure that should and can be followed in case of will to file an appeal against the decision rendered in absentia. This procedure is defined in Article 410 of his Code of Criminal Procedure where it is provided that the defense counsel can file an appeal against the decision given in absentia, when he is specially authorized by the defendant, is provided with a Power of Attorney issued in the form provided by law or by declaration at the hearing.

According to Article 410, in order for the legal representative of the defendant or the defense counsel to be able to exercise the right of appeal, the latter must have previously delegated by the defendant in person through a Nodatial Deed the opportunity to represent the defendant in exercising the right. to appeal against the decision rendered in absentia.

The Supreme Court has held different positions in different periods regarding the subjects which may have delegated the opportunity to exercise the right of appeal. The court also accepted appeals made by counsel authorized mainly by her or her family members, even though they did not have an authorization in the form required by law regarding the transfer of the right of appeal from the defendant to his defense counsel.

It should be noted that later through a unified decision by the Joint Panels of the Supreme Court that the court changed the case law by arguing that the right of appeal is an absolute right of the defendant and can be passed to his defense counsel only when it conforms to Article 64 of the Code of Civil Procedure and Article 410 of the Code of Criminal Procedure and must be done before the Notary Public and the rights of the defense counsel regarding the appeal (Joint Panels of the 
Supreme Court , 2014).

Article 415 of the Code of Criminal Procedure defines the time limits within which the appeal must be filed, which also stipulates that the defendant loses the opportunity to appeal after the expiration of the time limit specified in the code.

However, despite this provision which frames the law within a certain time limit, the Code has provided for a second option in terms of subjects who have not been able to use the right to appeal for reasons that are independent of their subject. This second possibility in favor of the defendant is expressed and sanctioned in Article 147. This provision stipulates that the prosecutor, the defendant, the victim, the accusing victim and the private parties are reinstated in time when they have not been able to meet the time limit due to the factual case with which we have in mind an unforeseen event and could not have been predicted by the defendant that would occur during exactly the same period, from where and until when it is determined, as well as the time frame to appeal.

On the other hand we also have the force majeure with which we understand random, natural, human or superhuman energy that the defendant has no opportunity to stop, resulting in the annulment of any of its actions to enable the realization of the complaint within the set deadlines. Despite the fact that there is a second possibility, certain subjects such as the prosecutor, the defendant, the victim, the accusing victim and the private parties for each of these parties mentioned in the code are not allowed to be reinstated more than once for each stage of the proceedings. Another essential condition provided in Article 147 in point 3 is the deadline when this appeal can be considered valid. The request for timely reinstatement must be made within ten days from the disappearance of the fact that constitutes a factual case or force majeure. Regarding the decision on the request related to the timely reinstatement, the body acting at the time of its submission decides on the latter. If the acting body at the moment of fulfilling the request for reinstatement in time rejects the request, an appeal can be made within 5 days. Then the last procedure is carried out by the court which examines the appeal in the counseling room within 10 days from the date of receipt of the acts.

With regard to the effects of reinstatement in time, Article 148 is provided which clearly provides that the court that has decided on time limit reinstatement, at the request of the party and as far as possible orders the repetition of actions in which the party had the right to participate.

The presence of the accused in the trial as a principle from the point of view of the legal process according to Article 6/1 of the ECHR, implies the physical presence of the accused. In the framework of this principle the ECHR in several decisions (see ECHR 22 September 1994 Lala v. Pays-Bas, 24.03.2005, Stoichkov v. Bulgaria) stated that

"the presence of the defendant is of great importance for the due process of law and justice, adding that the obligation to guarantee the accused the right to be present ... is one of the main elements of Article $6 "$

The Code of Criminal Procedure provides for judgment in absentia on the basis of strong procedural guarantees. In order to meet the parameters of a regular legal trial, rigorous notification must be guaranteed, first of all, according to the criminal procedural rules of the defendant for the process that is taking place against him. The court, based on the strict application of the notification rules and after verifying the application of the notification forms, may conclude that the defendant voluntarily withdrew from participating in it and continue the judgment in absentia. Non-compliance with the rules of notification leads to absolute invalidity of the process and the final decision based on article 128/1, letter "c" of the Code of Criminal Procedure and inability to repair the consequence caused by this type of invalidity according to the second paragraph of the aforementioned article, the case will be retried.

Regarding the absence of the defendant in the criminal proceedings, the Constitutional Court has determined that: 
"it is imperative that the defendant be aware of whether criminal proceedings have been instituted against him and, secondly, that he should voluntarily relinquish from participating in it. The court has reached this conclusion, because the waiver means an act of will on the part of the defendant, which as accepted by the theory of criminal law, in order to have a voluntary act, must first have a process of internal perception of reality by the defendant and then an internal decision-making process by him" (Constitutional Court, 2012).

The European Court of Human Rights has ruled that"to inform someone of an open trial against him is a judicial act of special importance that must be done in accordance with the procedural and essential requirements, which guarantee the effective exercise of rights by the defendant. Vague and informal information is not enough "(Sejdovic v. Italy, 2000). The Constitutional Court has emphasized that:

"the right of the defendant to participate in the trial, [...] is a personal constitutional right" (Decision 30, dated 17.06.2010).

As stated earlier in this paper, the Albanian criminal system recognizes and accepts as a valid trial the trial conducted in the absence of the defendant. Judgment in absentia, in any case, is considered valid only if the defendant has voluntarily decided not to participate in the trial, provided that the notifications regarding the criminal proceedings and the given decisions have been carried out in accordance with the form provided by the criminal procedural law and guaranteeing, in any case, that his interests are protected by a certain defense counsel himself or through one of the ways provided by law (Selimi, 2017).

In conditions when the defendant does not participate in the trial, when he has no opportunity to give statements, submit or contradict facts, to express himself regarding the evidence presented or to request the administration of other evidence, the notification of criminal proceedings and the decisions taken, as well as the provision of the possibility of defense with a lawyer and the appeal against the given decisions, are of exceptional importance to guarantee the right to a fair legal process, within the meaning of Article 42 of the Constitution and Article 6 of the European Convention on Human Rights (ECHR).

The Constitution of the Republic of Albania (Constitution), in Article 33 stipulates that: "Everyone has the right to be heard before being adjudicated. A person who is hiding from justice may not take advantage of this right." Article 43 of the Constitution stipulates that: "Anyone shall be entitled to file an appeal against a judicial decision before a higher court, except if otherwise provided in the Constitution".

The Constitutional Jurisprudence, in decision no. 30, dated 17.06.2010, has accepted that the defense counsel appointed by the parties, according to the conditions of article $48 / 3$ of the Code of Criminal Procedure, which provides that: "The appointment of the lawyer of a person who is detained, arrested or convicted to imprisonment, may be done by his relatives in the forms provided by paragraph 2, unless he has appointed one by himself", may be entitled to file an appeal against a court decision if certain conditions are met. The right of the defendant to participate in the trial, as well as to elect legal representatives is a personal constitutional right, which can not be transferred to family members. Also, the provision in Article $48 / 3$ on the possibility of relatives to provide a power of attorney for the defendant's defense counsel does not mean the transfer of the right to choose defense counsel from the defendant to the relatives, but also implies the exercise of the will of this defendant through the relatives. In other words, the defendant exercises this personal right through his family members, who have the objective opportunity to contact lawyers, in order for the latter to consider the possibility of obtaining the capacity of the defendant's legal counsel. In these circumstances, if there is a discrepancy between the will of the defendant and the will of his relatives, who have misinterpreted the will of the defendant or have had a different will for the legal counsel, the will of the defendant must prevail, who in any case may refuse or dismiss the defense counsel chosen by the relatives". 
However, the right to go to court is not absolute. This right may be part of the limitations, but the limitations must not be such as to impair the very essence of the right. They must pursue a legitimate aim and the means used must be proportionate to the aim sought to be achieved.

Resolution No. (75), 11 adopted by the Committee of Ministers of the Council of Europe "On the criteria for judgment in absentia" recommends that the governments of the member states apply the following minimum rules:

a) No one may be tried without having first been effectively served with a summons in time; b) The summons must state the consequences of any failure by the accused to appear at the trial;

b) Where the court finds that an accused person who fails to appear at the trial has been served (atteint) with a summons, it must order an adjournment if it considers personal appearance of the accused to be indispensable or if there is reason to believe that he has been prevented from appearing;

c) The accused must not be tried in his absence, if it is possible and desirable to transfer the proceedings to another state or to apply for extradition;

d) Where the accused is tried in his absence, evidence must be taken in the usual manner and the defense must have the right to intervene;

e) A judgement passed in the absence of the accused must be notified to him according to the rules governing the service of the summons to appear and the time-limit for lodging an appeal must not begin to run until the convicted person has had effective knowledge of the judgement so notified, unless it is established that he has deliberately sought to evade justice; g) Any person tried in his absence must be able to appeal against the judgement by whatever means of recourse would have been open to him, had he been present;

f) A person tried in his absence on whom a summons has not been served in due and proper form shall have a remedy enabling him to have the judgement annulled;

g) A person tried in his absence, but on whom a summons has been properly served is entitled to a retrial, in the ordinary way, if that person can prove that his absence and the fact that he could not inform the judge thereof were due to reasons beyond his control.

Thus, as it results from the determination of the criteria for judgment of the accusedin absentia, inter alia, the obligation of the court is foreseen, which in cases when there is no certainty whether the notification has been made for the defendant despite being formally performed.

\section{Conclusions}

As noted in this paper, the criminal process must be conducted in respect and guarantee of the rights of the defendant. One of the rights of the defendant in the criminal process is the right to be present at trial and to be heard. However, in many cases criminal proceedings can take place in absentia, ie in the absence of the defendant. In these cases the court must be very careful in making a decision on the declaration of absence, as its decision-making may bring procedural consequences for the defendant in absentia. Our Code of Criminal Procedure stipulated the conduct of the judgment in absentia but only after the court has made all efforts regarding the notification of the defendant. Only after all the rules on the notification of the defendant have been exhausted can the court proceed with the trial in absentia. However, in our case law there are many cases when the courts, although finding that the defendant was not aware of the trial registered with the court of first instance, decide to declare absence and continue the trial. This brings procedural consequences for these defendants who have no knowledge at all of a trial which is taking place against them. Therefore, we think that a regulation should be proposed, placing it as an obligation for the court to decide on the suspension of the trial in these cases and to order the defendant search. 


\section{References}

Islami, H., Hoxha, A., \& Panda, I. (2012),“Criminal Procedure” Tirana: Morava

Lara, D. (2019), “Commentary of Criminal Procedure”, Tirana: Morava

Selimi, S. (2017), "Criminal process of judgment in absentia”, Tirana

Constitutional Court. (2012). Decision no. 26, dated 08.05.2012. Tirana

Court, J. P. (2014). Decision no. 1, dated 10.03.2014. Tirana

Committee of Ministers of the Council of Europe. Resolution No. (75), 11 "On the criteria for judgment in absentia of the accused"

Constitutional Court. (2012). Decision no. 26, dated 08.05.2012. Tirana

Tirana District Court . (2019). Decision no. 3465, dated 22.11.2019. Tirana

Tirana District Court. (2020). Decision no. 321, dated 10.01.2020. Tirana 